\title{
A NEW PARADIGM OF CUSTOMARY INTERNATIONAL CRIMINAL LAW: The UN War Crimes Commission of 1943-1948 and its Associated Courts and Tribunals
}

\begin{abstract}
This article focuses on the United Nations War Crimes Commission's significant contribution to the development of customary international criminal law defined by the development of international legal standards and proceedings to combat impunity and promote justice. It draws on the Commission's official history and its increasingly open archives in order to provide an overview of the UNWCC and its work, its members and its legacy for the contemporary era of international criminal law. The article firstly places the Commission in its historical context through the events and agreements that led to its creation and provided the legal character of the UNWCC. The defining characteristics of the Commission are afterwards described: the nations involved, the committee structure it formed and the sub-commission located in the Far East. Lastly, the accomplishments of the Commission are emphasised and criticisms of its work are presented. The article concludes with a discussion on the legacy of the Commission's work and a possible future research agenda.
\end{abstract}

\section{INTRODUCTION}

In October 1943, as World War II raged on in Europe and Asia, representatives of seventeen Allied governments met at the UK Foreign Office in London to create a multilateral organization to mobilize international retributive justice efforts. These states were motivated by the need to create both a legal and a military response to what they saw as unprecedented atrocities being

\footnotetext{
* *Dr. Dan Plesch is the Director of the Centre for International Studies and Diplomacy (C.I.S.D.) at SOAS, University of London. E-Mail: dp27@soas.ac.uk.

** Shanti Sattler is the Assistant Director at the War Crimes Project at C.I.S.D. E-Mail: ss138@soas.ac.uk.
} 
committed against the military and civilian populations of the countries attacked by the Axis. On 20 October 1943, the government representatives began formal discussions about the advancement of international criminal law and the standards of how to bring justice to the international community. The new organisation was called the United Nations War Crimes Commission (UNWCC) in line with a number of other civilian multinational organizations created in this period. ${ }^{1}$ By the time the UNWCC closed in March 1948, the Commissioners and their respective nations were responsible for making prima facie judgments on 36,000 cases put to the Commission by member states. These judgments resulted in over 2,000 criminal trials ${ }^{2}$ conducted around Europe and the Far East before national military civil courts and tribunals. Furthermore, through the forum of the UNWCC, the Commissioners debated and voted on pressing issues of international criminal and humanitarian law. The standards and concepts agreed upon by the Commissioners were transmitted to member states that very often adopted the views of the Commission. The views of the Commission and its members also influenced the London Charter for the International Military Tribunal (IMT) in 1945. Viewed all together, the collaborative multilateral efforts that took place through the UNWCC between 1943 and 1948 generated a significant contribution to the development of customary international criminal law defined by the development of international legal standards and proceedings to combat impunity and promote justice. ${ }^{3}$

The efforts of the Commission and its members are largely overlooked and forgotten in a historical narrative that has long focused almost entirely on the IMT conducted at Nuremberg and Tokyo. From this perspective, the work of the Commission and the score of associated national and military tribunals constitute a new paradigm of customary international criminal law.

\footnotetext{
${ }^{1}$ In 1942 the Allies adopted the name 'United Nations' as the formal name for their alliance. This action by the United Nations committed the powers fighting the Axis both to reject a separate peace and to a series of political objectives. These included a commitment "to preserve human rights and justice in their own lands as well as in other lands", 26-nation Declaration by United Nations, January 1942. For more background on the United Nations alliance and the creation of the UNWCC, see D. Plesch, America, Hitler and the UN (London, I.B. Tauris \& Co Ltd., 2011), E. Schwelb, 'The United Nations War Crimes Commission' (1946) 23 British Yearbook of International Law 363, 364 and A. J. Kochavi, Prelude to Nuremberg: Allied War Crimes Policy and the Question of Punishment, (Chapel Hill, University of North Carolina Press, 1998) chapter two.

${ }^{2}$ The United Nations War Crimes Commission (ed.), History of the United Nations War Crimes Commission and the Development of Laws of War (His Majesty's Stationary Office, 1948) 518.

${ }^{3}$ We discuss the relationship of the UNWCC to customary international law in our article Changing the Paradigm of International Criminal Law: Considering the Work of the United Nations War Crimes Commission of 1943 - 1948, 15 The International Community Law Review 203-223.
} 
This article draws on the Commission's official history published in $1948^{4}$, and its increasingly open archives in order to provide an overview of the UNWCC and its work, its members and its legacy for the contemporary era of international criminal law. We will first look at the historical context of the Commission through the events and agreements that led to its creation and provided the legal character of the UNWCC. Following this overview, we describe the Commission through its defining characteristics: the nations involved, the committee structure it formed and the sub-commission located in the Far East. In the next section, we highlight the accomplishments of the Commission and criticisms of its work before concluding with a discussion on the legacy of its work and the future research agenda.

\section{THE HISTORICAL CONTEXT OF THE UNWCC}

When the members of the Commission first began to work together in 1943, the representatives commonly referred to several established tenants of international law as they sought to establish legal ground for their work. These agreements and documents provided the legal precedent for the work of the UNWCC and the national trials. During the operations of the Commission, an internal legal committee worked continuously to expand and develop these already existing legal

concepts. ${ }^{5}$ Among the agreements most cited by the Commission were the Hague Conventions of 1899 and 1907. The Hague Conventions provide the first modern codification of actions in war that the member states considered should be regarded as illegal and marked significant progress in the development of international cooperation concerning the development of war crimes and laws of war.

The Commission of Responsibilities of the Paris Peace Conference later accompanied the standards of The Hague Conventions at the end of World War I in 1919. While these efforts largely failed to meet their objective of dealing with issues of prosecution for war crimes committed during World War I, the Conference developed a further codification of thirty-two

\footnotetext{
${ }^{4}$ The United Nations War Crimes Commission (ed.), History of the United Nations War Crimes Commission and the Development of Laws of War was published in March 1948 by His Majesty's Stationary Office (History of the $U N W C C$ ). It was written by the members of the UNWCC and its secretarial staff with the purpose of recording the work of the Commission for study by future students and scholars of international law.

${ }^{5}$ The United Nations War Crimes Commission, Information Concerning Human Rights Arising from Trials of War Criminals, U.N. Doc E/CN.4/W.19 $125 \quad(15 \quad$ May 1948) <http://www.unwcc.org/wpcontent/uploads/2013/04/UNWCCUN-HRs-Report.pdf> .
} 
acts that it considered to be war crimes. Members of the UNWCC used this "Versailles List" from the Paris Peace Conference as both as legal precedent and also as inspiration for improving international efforts in this regard ${ }^{6}$.

Indeed, despite the progress established by The Hague Conventions and the Paris Peace Conference, the state of international criminal law at the outbreak of the Second World War was complex and incomplete. The Commission provided one of the earliest descriptions of this context in a report for the UN Human Rights Division that was published in 1948 and restricted to public access until the late $1980 \mathrm{~s}^{7}$ This report detailed the Allied position from the perspective of the members of the Commission in an effort that describes the existing legal precedent at the time:

War has been described as organized murder and desolation. But there was a question of great moment because of the rival contentions advanced on the two sides. One side, that of the Axis, asserted the absolute responsibility of belligerents, who, it was asserted, were under no obligation to respect human rights, but were entitled to trample them underfoot wherever the military forces found them inconvenient for the waging of war. This is the totalitarian war as envisaged by the Axis powers. This doctrine was repudiated as contrary not only to morality but to recognized international law which prescribed metes and bounds for the violation even in war of human rights. This latter doctrine involved also the further principle that there was individual responsibility for violations of human rights in war time, beyond the limits permitted by the law of war. The idea of individual responsibility, if it was to be conceived in terms of law involved a legal system and procedure, in order to decide the question of individual criminality. ${ }^{8}$

The standards of laws of war referred to by the Commission reflect their regard for international treaties and conventions established prior to World War II, specifically The Hague and Geneva Conventions and the Pact of Paris. However, the generality of the terms of these international enactments required further definition and strengthening to in order to be appropriately applied to the complex context faced by the Commission.

\footnotetext{
${ }^{6}$ UNWCC, 2 d mtg. (2 December 1943), U.N.W.C.C. $3^{\text {rd }} \mathrm{mtg}$. (9 December 1943) and UNWCC C 1, C 87 (1); See Information Concerning Human Rights Arising from Trials of War Criminals (n 1) 8, 146-180.

${ }^{7}$ Ibid., ii.

${ }^{8}$ Ibid.
} 
Public international statements condemning enemy atrocities and promising retribution also fuelled the creation of the legal and political work of the multilateral collaboration that later became the Commission. Representatives were also propelled by public opinion and civil society initiatives, notably the London International Assembly. ${ }^{9}$ Formal statements began in 1940 with the Czech and Polish governments releasing a joint statement in November concerning the unprecedented nature of Nazi atrocities. ${ }^{10}$ A statement from the Polish government was released shortly thereafter that informed the public about the Nazi attempt to eradicate Polish national identity. ${ }^{11}$ Following Czechoslovakia and Poland, Roosevelt and Churchill released parallel statements in October 1941 promising "retribution". In his statement, Churchill emphasized that atrocities were occurring "above all behind the German fronts in Russia". He continued by adding that retribution "[for] these crimes must henceforward take its place among the major purposes of the war". ${ }^{12}$ While robust and judicial in tone, these statements did not make specific reference either to the plight of the Jews or to a legal process. The Soviet Foreign Ministry also issued notes on German atrocities to all nations it had diplomatic relations with in November 1941 and again in $1942 .{ }^{13}$ These statements included descriptions of Nazi pogroms, particularly those at Lodz.

The first multilateral statement setting out a judicial response to Nazi atrocities as an Allied war aim was released in January 1942. Belgium, Czechoslovakia, Free France, Greece, Luxembourg, Netherlands, Norway, Poland and Yugoslavia issued a joint statement on Punishment for War Crimes at St James's Palace in London that was also promptly endorsed by China. ${ }^{14}$ The St. James Declaration stated:

...whereas international solidarity is necessary in order to avoid the repression of these acts of violence simply by acts of vengeance on the part of the general public, and in order to satisfy the sense of justice of the civilised world...[the signatories] place among their

\footnotetext{
${ }^{9}$ See particularly, the contribution of C. Stahn include in this volume.

10 'Czechoslovakia and Poland', The Times (12 November 1940) 3.

11 'German Crimes in Poland', The Times (20 December 1940) 3.

${ }^{12}$ M.E. Bathurst, 'The United Nations War Crimes Commission', (1945) American Society of International Law, $565-8$.

13 'German Atrocities (HMSO for the Soviet Embassy, London, 7 November and 6 January 1942) and The United Nations War Crimes Commission', in History of the UNWCC (n 4).

${ }^{14} \mathrm{~T}$. Lie (then the Norwegian Foreign Minister and future first Secretary-General of the United Nations) was among the signatories.
} 
principal war aims the punishment, through the channel of organised justice, of those guilty of or responsible for these crimes, whether they have ordered them, perpetrated them or participated in them... ${ }^{15}$

General Wiadyslaw Sikorski, Prime Minister of Poland and Chairman of the Conference, explained that the practical purposes of the Declaration were to warn the enemy and offer a "glimmer of hope" to the peoples of occupied Europe. He stated bluntly that "the Declaration resolutely turns International Law in a new direction". ${ }^{16}$ With the Declaration, the signatory states also brought attention to the issue of individual responsibility including command responsibility and collective (participatory) responsibility. Furthermore, the St James Declaration explicitly put the Axis on warning that they would face a judicial process.

The British Foreign Secretary, Anthony Eden, attended the meeting at St James's Palace along with the US Ambassador and other allied representatives, but none of the Big Three were ready to endorse the policy. All of the original signatory states were under enemy occupation. Their notable efforts demonstrated the explicit intent to bring the will of the international community to assist in maintaining civilised values and suppress the risk of lynch mobs after victory. By October, the Big Three Allied powers had all signed the Declaration following representations from the signatories.

Following this endorsement, the exiled governments further pushed both the British and US for the creation of a United Nations War Crimes Commission. ${ }^{17}$ Shortly after the meeting at St. James's Palace in July 1942, the British government endorsed the creation of a 'United Nations Commission on Atrocities'. Its function was declared to be fact-finding body and to produce reports. The British advised, however, that "[t]he suggestion of some sort of international court for the trial of war criminals is to be deprecated. Nor is it necessary or desirable to create a new body of international law, for war crimes are already sufficiently well defined". ${ }^{18}$ Nevertheless, Roosevelt issued a public declaration on 21 August 1942 stating:

\footnotetext{
${ }^{15}$ Punishment for War Crimes: The Inter-Allied Declaration Signed at St. James's Palace London on $13^{\text {th }}$ January, 1942 and Relative Documents (London: His Majesty's Stationary Office, 1942).

${ }^{16}$ Ibid., 7.

${ }^{17}$ To put this use of the term 'United Nations' in context, it must be noted that the group of nations now commonly referred to as 'The Allies' formally called themselves, 'The United Nations' from 1 January 1942 onwards. For more information, see Plesch, America, Hitler and the UN (n 1).

${ }^{18}$ United States Department of State, 'Foreign Relations of the United States diplomatic papers' 1 General, British Commonwealth, The Far East (1942) 45ff.
} 
The United Nations are going to win this war. When victory has been achieved, it is the purpose of the Government of the United States, as I know it is the purpose of each of the United Nations, to make appropriate use of the information and evidence in respect to these barbaric crimes of the invaders, in Europe and in Asia. It seems only fair that they should have this warning that the time will come when they shall have to stand in courts of law in the very countries which they are now oppressing and answer for their acts. ${ }^{19}$

This and his subsequent statements and actions belie the oft repeated claim that he considered seriously mass executions of some 50,000 Nazis in the place of legitimate justice processes.

In October 1942, the British and US formally endorsed the creation of a 'United Nations Commission for the Investigation of War Crimes'. ${ }^{20}$ The name was later changed to the United Nations War Crimes Commission as operations began. Negotiations on the terms of reference of the UNWCC took a year until its official creation 20 October 1943. A few days after the first meeting of the Commission, British, Soviet and US government representatives meeting in Moscow issued a declaration that set out the major powers' general approach to war crimes. The Moscow Declaration was made on behalf of the United Nations alliance reserving the fate of the German leadership to the Big Three, but announcing the policy that stated that suspected Axis war criminals would be tried by and in the nations where they had committed their crimes and that crimes without clear geographical reference would be tried based on joint decisions by the Allied governments. ${ }^{21}$

Despite this initial support from the Soviet government for the Moscow Declaration, the Soviet Union did not participate in the UNWCC for numerous reasons. The Soviet Union criticized the terms of reference of the UNWCC for not going far enough to investigate and punish suspected war criminals, and especially for not making preparation for committing a war of aggression and crimes against humanity into war crimes. The British refusal to accuse Rudolph Hess (The Deputy Fuhrer who had parachuted into Britain on a diplomatic mission in 1941) of war crimes was also vehemently opposed by Moscow. ${ }^{22}$ The Soviet Union pursued its own war crimes trials.

\footnotetext{
${ }^{19}$ C. Hull, The Memoirs of Cordell Hull (London, Hodder and Stoughton, 1948) 1184.

${ }^{20}$ Hansard, House of Lords, 17 December 1942, Col. 577.

${ }^{21}$ Moscow Conference, Statement on Atrocities, October 1943, <http://avalon.law.yale.edu/wwii/moscow.asp $>$.

${ }^{22}$ A. J. Kochavi, (n 1 above) 222-230.
} 


\section{CHARACTERISTICS OF THE COMMISSION}

The UNWCC member states were Australia, Belgium, Canada, China, Czechoslovakia, France, Greece, India, Luxemburg, the Netherlands, New Zealand, Norway, Poland, the United Kingdom, the United States and Yugoslavia. All actively participated in the Commission from the beginning of its operations or shortly thereafter. South Africa was only involved in setting up the UNWCC and did not host national trials. Denmark joined the UNWCC in July 1945. In February 1944, a Commissioner suggested that Brazil and Mexico might join the UNWCC based on experiences of suffering, but neither country pursued membership. ${ }^{23}$

Figure 1: Nations Involved in the UNWCC

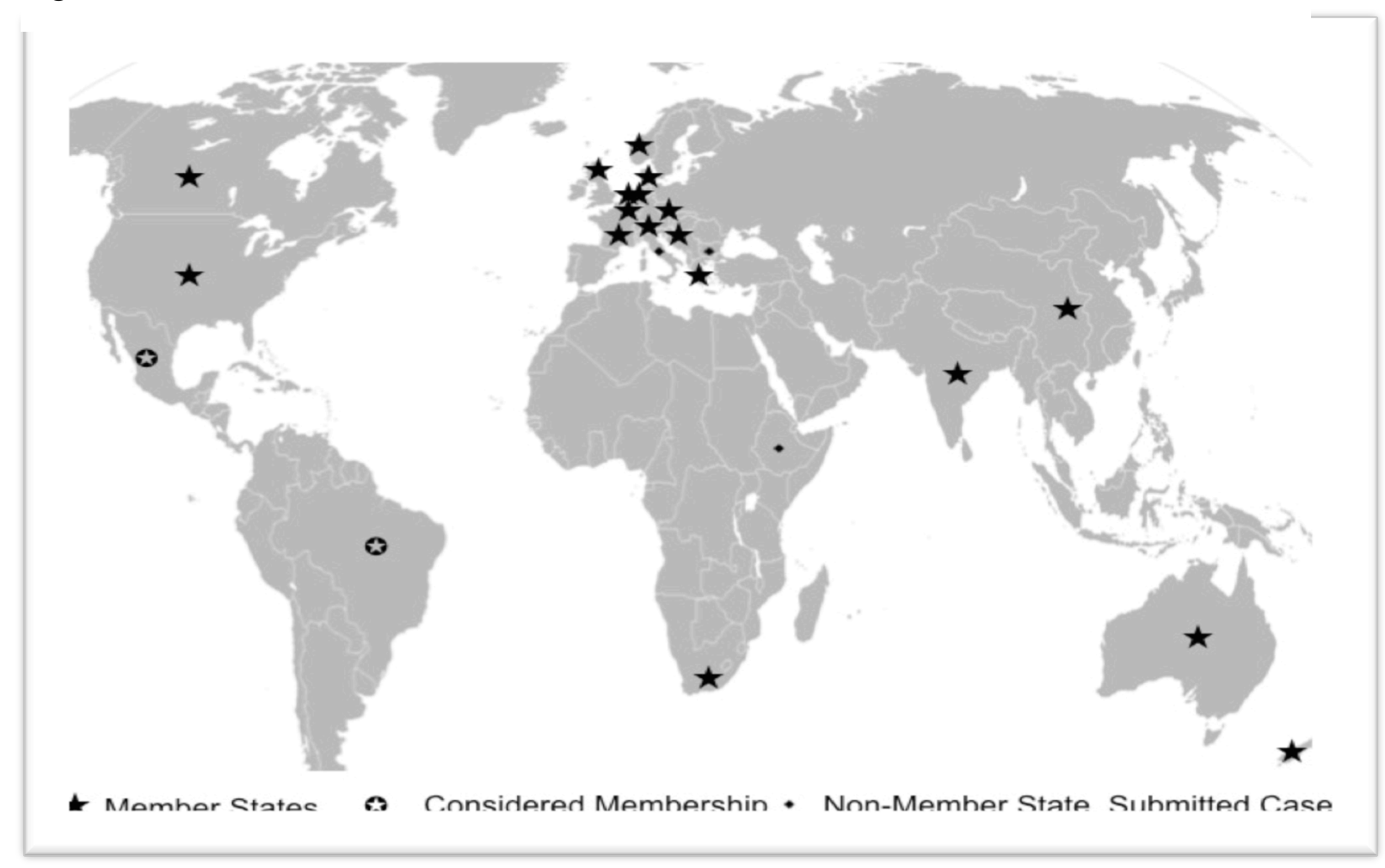

Upon its creation, the Commission was given three specific duties by the member countries:

\footnotetext{
${ }^{23}$ UNWCC, 11th mtg. at 1 (29 February 1944).
} 
1. To investigate and record the evidence of war crimes, identifying where possible the individuals responsible;

2. To report to the governments concerned cases in which it appeared that adequate evidence might be expected to be forthcoming;

3. To make recommendations to member governments concerning questions of law and procedure as necessary for them to be able to fulfil their role of conducting trials. $^{24}$

The Commission quickly organized into three committees that met weekly. The first committee (Committee I) was dedicated to facts and evidence. The second committee (Committee II) handled matters of enforcement and the third committee (Committee III) served as the forum for dialogue on legal affairs.

The nations involved set up respective National Offices within their governments to liaise with the Commission, coordinate investigations, collect evidence and create new legal structures to handle war crimes where necessary. ${ }^{25}$ All of the National Offices reported directly to the main UNWCC headquarters in London as they conducted investigations and constructed lists of suspected war criminals for review from 1944 to the end of 1947. A National Offices Conference was held in London in May and June $1945 .^{26}$ The conference discussed policy and practice for the pursuit and trial of war criminals and its papers include a number of municipal statutes for war crimes trials. As far as we are aware, the Commission conducted the only comparative analysis of the different national practices to take place during this time. This analysis is presented in a report the Commission submitted to the UN in 1948. The report provides a frankly incomplete assessment that invited more research. ${ }^{27}$ No additional research on the work of the national offices has been conducted to the best of our knowledge.

In addition to setting up national offices, some West European governments in exile in London created enabling legislation for war crimes courts. For example, by August 1943 Belgium and the Netherlands had passed laws creating courts to try war crimes cases in their own

\footnotetext{
${ }^{24}$ History of the UNWCC (n 4).

${ }^{25}$ The Netherlands laws for the trial of war criminals were enacted in 1943 and the French in 1944.

${ }^{26}$ Minutes and papers of the UNWCC National Offices Conference.

${ }^{27}$ Information Concerning Human Rights Arising from Trials of War Criminals (n 5 above) 125-145 and Appendix.
} 
countries. ${ }^{28}$ Through its committee structure, the UNWCC supported the National Offices in conducting their investigations and also investigated some cases on its own by maintaining a small staff team that also liaised with governments through the National Offices. ${ }^{29}$ The Commission was ultimately responsible for issuing prima facie decisions on the cases brought to it by the national offices that resulted from their investigation efforts. These decisions were made through an ex parte process. ${ }^{30}$ The UK provided facilities for the Commission, but the staff was international and all member states contributed equally to funding the general operations and the operations of their respective National Offices.

Figure 2: Core Process of UNWCC Investigation and Prosecution Operations

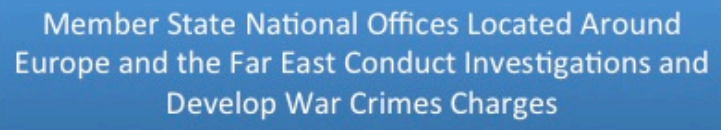

Member State

National Office

Sends Case to

UNWCC Office

in London
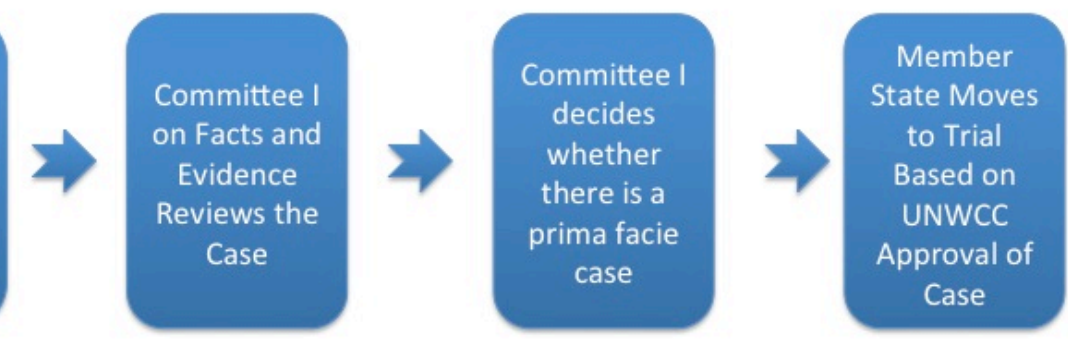

Member states only submitted cases that they wished included amongst the lists of accused, suspected war criminals and material witnesses. The UNWCC published all of the lists in their records. Where prosecutions resulted, states were encouraged to send summary trial reports to be recorded by Committee I. This process was incomplete at the time of the Commission's hasty

\footnotetext{
${ }^{28}$ E/CN.14-AM9 (1948). For the Netherlands, see page 130 [Netherlands Extraordinary Penal Law Decree of 22 December 1943 (Statute Book D. 61) and the Decrees of 22 December 1943, (Statute Book D. 62)]. For Belgium, see page 291.

${ }^{29}$ UNWCC, Internal Memo (18 Apr. 1945).

${ }^{30}$ Some criticism of this has been that it was based on hearsay evidence, a matter discussed by the UNWCC itself. See Information Concerning Human Rights Arising from Trials of War Criminals (n 1). It appears to us that the colloquial sense of 'hearsay' as gossip has been used to denigrate the work of the UNWCC as a whole. Also see the UNARMS application package for the UNWCC.
} 
closure in 1948, with many countries being unable to complete and process their reports in time to be included in the Commission's publications.

The efforts of the National Offices and Committee I were complemented for a short time by the enforcement work of Committee II that was led by former US Congressman Ambassador Herbert Pell. ${ }^{31}$ Committee II's work was initiated in the spring of 1944 when the UNWCC endorsed the proposal of several enforcement mechanisms. These mechanisms included a war crimes office in enemy territory ${ }^{32}$ that contributed to the creation of CROWCASS ${ }^{33}$ under the command of General Dwight D. Eisenhower, Supreme Commander Allied Expeditionary Force. ${ }^{34}$ Other initiatives include a detailed proposal for mixed military tribunals under the major allied commands that was later adopted ${ }^{35}$ by many states. In the specific case of the UK, the discussions within the Commission on how to bring accused war criminals to trial "ultimately resulted" in the issuing of the Royal Warrant and the creation of the British War Crimes Executive in July $1945 .^{36}$

Committee III was in operation for the duration of the existence of the Commission. The work of Committee III was marked by the active participation of key members of the exile governments; the Committee received complex legal questions from the different nations in order to generate debate and ultimately arrive at decisions and recommendations for the practice of the National Offices.

\footnotetext{
${ }^{31}$ See the contribution by G. Cox, in this volume..

${ }^{32}$ UNWCC $21^{\text {st }} \mathrm{mtg}$. at 3 (6 June 1944) and the accompanying UNWCC Doc. C24, as well as UNWCC $22 \mathrm{~d}$ tg. at 3 (13 June 1944) and the accompanying UNWCC Doc. C30.

${ }^{33}$ CROWCASS is the Central Register of War Criminals and Security Suspects, Supreme Headquarters Allied Powers in Europe.

${ }^{34}$ UNWCC 32d mtg.at 2-7 (19 September 1944). Also see UNWCC Doc. C 52(1) Recommendation in Favour of the Establishment by Supreme Military Commanders of Mixed Military Tribunals for the Trial of War Criminals.

${ }^{35}$ UNWCC 32d mtg. (19 September 1944). The Commission approved the adoption of a proposal for a United Nations War Crimes Court (See the accompanying UNWCC Doc. C49, Doc. C50 and Doc. C58 Explanatory Memorandum).

${ }^{36}$ Memorandum from the Treasury Solicitors Office for the Attorney General, (1945) 1,2,4. UK National Archives TS26, 897, 27-33.
} 
Figure 3: The UNWCC Committee and Sub-

\section{Commission Structure}

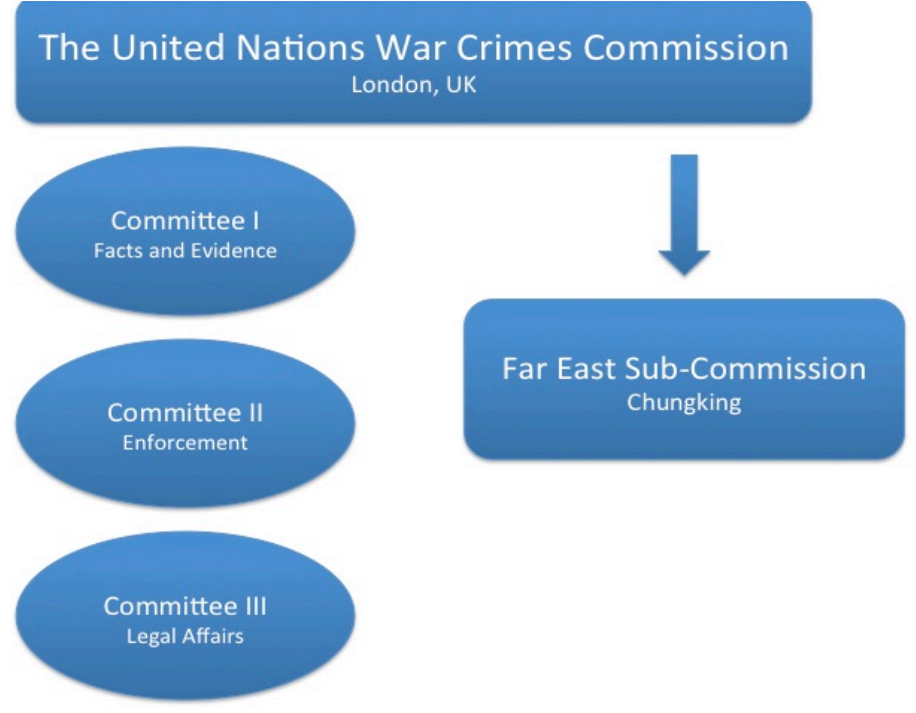

In addition to the national investigations and trials, the Commission helped design and initiate the establishment of military tribunals to address situations involving particularly complex crimes. Crimes addressed by military tribunals included incidences that didn't have specific geographic locations and crimes committed against Allied nationals in Germany and across parts of the Far East under various forms of colonial administration. ${ }^{37}$. The military authorities were primarily from the US and the UK and were also responsible for aiding their respective nations in investigations and holding trials. As well as meeting the need to address complex situations, the integration of military authorities was also due in part so that trials could be conducted "without waiting for the initiative of any one Government on the matter". ${ }^{38}$ Collectively, Allied military authorities conducted a large number of trials around Europe and the Far East. ${ }^{39}$

\footnotetext{
${ }^{37}$ See the October 1945 Trial of Kapitanleutnant Heinz Eck and Four Others accused of killing crew members of the Greek steamship 'Peleus' in a British Military Court for the Trial of War Criminals.

${ }^{38}$ UNWCC, 33d Mtg. 33 at 6 (26 September 1944).

${ }^{39}$ The UNWCC's reliance on military authorities was in part due to the UNWCC's commitment to providing justice that was swift and effective. The meaning of this was debated among members throughout the existence of the UNWCC. The internal document 'Recommendation in Favour of the Establishment by Supreme Military Commanders of Mixed Military Tribunals for the Trial of War Criminals' of 26 September 1944 declared that the strategy would be used in part "...so that no criminals escape trial and punishment because of the inability to effect a speedy trial" (UNWCC Doc. C.52(1)). In hesitation, French representative M. Gros addressed this idea in a written statement submitted at the UNWCC's thirty-first meeting on 12 September 1944. His first point stated, "[a]lthough the notion of swift justice is found in manuals of military law, 'justice' is something that does not admit of qualifying adjectives". Also see History of the UNWCC (n 1$) 5$.
} 
In addition to military tribunals and the National Offices, the Commission hosted a subcommission in the Far East. ${ }^{40}$ At the founding meeting in October 1943, China made a proposal to the members of the Commission for the creation of a Far Eastern and Pacific Sub-Commission to represent and conduct the work of the UNWCC in the Far East. ${ }^{41}$ The Sub-Commission was created in June 1944. Its inaugural meeting was held on 29 November 1944 in Chungking, then the capital of China and it continued to operate through $1948 .{ }^{42}$ Approximately $90 \%$ of the cases presented to the Sub-Commission came from the Chinese national office. China went on to conduct war crimes tribunals in Nanking, Hangkow, Canton, Mukden, Taiyua, Peipine, Hsuchow, Tsinan, Shanghai and Formosa. ${ }^{43}$

The UNWCC concluded its work at its headquarters in London as well as the National Offices in 1948. It is widely argued that the US and the UK exerted strong influence in the matter of hastily closing down the Commission. ${ }^{44}$ Chris Simpson and others argue convincingly that the main reason was to rehabilitate Nazis into Germany. ${ }^{45}$ In 1948 the Commission passed its records to the United Nations Organisation. In the same year, the Commission issued its report on the development of legal human rights standards following World War II. In this report, the UNWCC called for further research into the war crimes trials at the end of World War II by a range of academic disciplines. ${ }^{46}$ The intent was futile, for the entire archive was classified until 1987 when the rules of access were loosened in theory. However in practice, with a few exceptions, the entire archive remained closed to public access until recently. ${ }^{47}$

In the fall of 2011, the United Nations Archives and Records Management Section (UNARMS) agreed to allow access to bona fide researchers to the majority of the archive including all of the meeting minutes and trial summaries. This adjustment in the enforcement of

\footnotetext{
${ }^{40}$ See the contribution of W. W. Lai in this volume. .

${ }^{41}$ See UNWCC 15th mtg. at 1-5 (25 April 1944); History of the UNWCC (n 1) 129.

${ }^{42}$ Ibid., 129.

${ }^{43}$ Ibid., 516.

${ }^{44}$ We rely on Chris Simpson's analysis of the closure of the UNWCC. He argues that the demise of the UNWCC was instigated by US officials in order to facilitate the rehabilitation of Nazis into the Western Zones of Germany. See C. Simpson, The Splendid Blond Beast: Money, Law and Genocide in the Twentieth Century (Monroe, Maine, Common Courage Press, 1995), 13.

${ }^{45}$ See the contribution of C. Simpson in this volume.

${ }^{46}$ Information Concerning Human Rights Arising from Trials of War Criminals, (n 5 above) vi.

${ }^{47}$ In order to gain access to view the UNWCC archives at the United Nations Archives and Records Management Section, UN rules dictate that researchers must first write a letter to their national mission to the UN to explain their research and that it is bona fide. The UN mission then must write a letter to the office of the UN Secretary-General who has the final approval. For more information and the application and guidelines for access, see $<$ https://archives.un.org/content/access-and-declassification $>$. The United States recently requested a copy of the entire UNWCC archive in partnership with the United States Holocaust Memorial Museum.
} 
the rules came following efforts of the War Crimes Project at SOAS, University of London to open the archives. Working in partnership with the War Crimes Project, the Office of the Prosecutor of the International Criminal Court (ICC) has made this large section of the archive available to the wider public. The section that remains closed to the general public includes 36,000 pre-trial charge files that detail various charges, witness statements and testimonies.

Prior to the partial opening of the UNWCC archives held at UNARMS, various national archives also made sections of the Commission's records public. These nations include the US, the UK and Australia among others. In October 2013, the US government announced that it was exercising its right as a member of the Commission to take a copy of the entire UNWCC archive, including the charge files, for the use of the US Holocaust Memorial Museum.

\section{THE UNWCC'S CONTRIBUTION TO THE DEVELOPMENT OF INTERNATIONAL CRIMINAL LAW}

The UNWCC was the first multilateral initiative to successfully conduct widespread investigations into heinous crimes of war and provide structure to prosecute suspected war criminals in the modern period. This in and of itself amounts to remarkable action. The work and structure of the Commission also serve as a rare example of constructive action and mobilization between nations during times of war concerning justice. The urgency of the times of war, in particular the influence of the exiled governments in this regard, prompted the US and the UK in particular to heed to the proposals of the Commission and actively participate. ${ }^{48}$ The practice of mobilization of multilateral collaboration and national investigations stands in direct contrast to subsequent international criminal justice efforts of the post-Cold War period. It is also important to note that the UNWCC considered a draft constitution for a United Nations International Criminal Court. ${ }^{49}$ The concept of developing an international criminal court was discussed in detail among members but was not adopted by member states. ${ }^{50}$

\footnotetext{
${ }^{48}$ A. J. Kochavi, (n 1 above) 4.

49 See the contribution of W. Schabas in this volume.

${ }^{50}$ UNWCC, 33d mtg. at 6 (26 September 1944) and UNWCC Doc. C51 Draft Convention for the Establishment of a United Nations War Crimes Court (30 September 1944).
} 
Another stark contrast to the international criminal tribunals of today is the Commission's prioritization of quick and efficient tribunals. This was also due in large part to the overwhelming sense of urgency felt by the nations at the time. From the initial days of the designing of the UNWCC structure and operations, UK Foreign Secretary Anthony Eden specifically argued for trying and punishing suspects immediately after the war in part to ensure rapid justice and in part to prevent citizens from taking the law into their own hands. He acted through the desire to avert a situation involving prolonged trials that would delay the restoration of peace in Europe and the Far East. ${ }^{51}$

By the time the UNWCC published its official history in 1948, 36,529 individuals and units had been charged by the governments and listed by the UNWCC. ${ }^{52}$ The Commission had received a total of 8,178 cases from the member governments. ${ }^{53}$ The number of people involved in the investigations of the Commission included 3,028 "war criminals and material witnesses" that were part of the Far East and Pacific Sub-Commission's lists. ${ }^{54}$ In addition to these cases, governments that were not members of the Commission also submitted cases and individuals for its review.

In History of the UNWCC, it is reported that approximately 2,000 associated trials took place around Europe and the Far East between the fall of 1945 and March of 1948 involving nearly 25,000 individuals. Many of the trials recorded in History of the UNWCC involved more than one defendant, which was pursuant to the harsh and complicated nature of many of the crimes committed during the war particularly in occupied territories. It states further that the 2,000 trials resulted in verdicts of death sentences and imprisonment for over 24,000 "minor" criminals of World War II. ${ }^{55}$ Some 5,193 individuals were acquitted by the National Office trials and 148 cases were "not accepted" ${ }^{56}$ because Committee I was not satisfied that there was sufficient evidence to justify a prosecution of the persons or units charged ${ }^{57}$ In these cases, nations were often asked by Committee I to present more evidence for further consideration before the case was dropped.

\footnotetext{
${ }^{51}$ A.J. Kochavi (n 1) 30.

${ }^{52}$ History of the UNWCC (n 1) 509.

${ }^{53}$ Ibid., 508.

${ }^{54}$ Ibid., 514.

${ }^{55}$ Ibid., 518.

${ }^{56}$ Ibid.

${ }^{57}$ Ibid.,531.
} 


\section{THE DEVELOPMENT OF KEY INTERNATIONAL CRIMINAL LAW ISSUES}

The details of the national investigations and trials provide significant insight into the work of the Commission and the responsibility of its members in developing key aspects of international criminal law. Indeed, the accomplishments of the UNWCC also involve the Commission's work on specific complex issues of international criminal law, many of which remain contentious today. In this section, we provide short summaries of some of the three primary issues that the Commission included in its investigations and trials: the crime of aggression, the defense of superior orders and issues around environmental Degradation. Additional key issues are addressed in articles included in this symposium.

\subsection{The Crime of Aggression}

The issue of the crime of aggression was present in the Commission's debates from the very beginning of its operations. The members recorded in History of the UNWCC that "[b]y far the most important issue of substantive law to be studied by the Commission and its Legal Committee was the question of whether aggressive war amounted to a criminal act". 58 Faced with complex questions related to the underdeveloped and highly contentious topic in the complex context of World War II, the Commission sought legal ground in the Kellogg-Briand Pact of 1928. The Kellogg-Briand Pact sought to address the concept of aggressive war, explicitly stating that the contracting parties "condemn recourse to war for the solution of international controversies" 59 and agree that settlement and solution for all disputes and conflicts should be sought only through pacific means. ${ }^{60}$

In History of the UNWCC, the members argued that in the context of the World War II, "there are clear precedents for the rule that it is an unlawful act to start and wage an aggressive war. It has indeed been long held by humanity that he who does such a thing is guilty of a

\footnotetext{
${ }^{58}$ Ibid., 180.

${ }^{59}$ Kellogg-Briand Pact of 1928, Article I.

${ }^{60}$ Kellogg-Briand Pact of 1928, Article II.
} 
supreme offense" ${ }^{61}$ Despite the seemingly clear legal support for the launching and waging of a war of aggression being against international law, the political situation of the time limited the advancement of this principle just as it does today and is was not until after the London Charter was concluded in August 1945 that the principle of aggressive war was endorsed by the Commission. ${ }^{62}$

However, the August 1946 trial of Takashi Sakai conducted by the UNWCC supported Chinese War Crimes Military Tribunal in Nanking is evidence of the Commission's support for the concept on legal grounds. The Japanese military commander was charged with crimes against peace and crimes against humanity. His incitement of numerous aggressive acts of atrocity against Chinese civilians while working in the country is directly referenced in the trial report. $\mathrm{He}$ was found guilty "of participating in the war of aggression" and sentenced to death. ${ }^{63}$

Following the debate within the Commission and the Sakai trial, Wright stated in History of the UNWCC, "I am quite satisfied that in the future, even though other forces may temporarily and on occasion prevail, the nations of the world will not let the principle go". ${ }^{64}$ However, it is clear that issues surrounding the crime of aggression continue to be contentious even in a contemporary context. This is most clearly demonstrated by the ambiguous nature of the conclusions of the Kampala Conference in 2010 that presented the ICC with the opportunity to incorporate the concept into the Rome Statute. While a historic agreement was reached on the adoption of a definition of the concept ${ }^{65}$, the ICC will not be able to enforce the crime until 2017 at the earliest.

The Trial of Takashi Sakai does not provide indisputable precedent on the crime of aggression; however, it does represent support for the adoption of the principle that remains relevant today. Additional precedent may be found in the national legislation for war crimes tribunals and in national practice. A question for further research is whether China pursued case other than the Sakai case on the basis of the charge of making aggressive war or crimes against

\footnotetext{
${ }^{61}$ History of the UNWCC (n 1) 17.

${ }^{62}$ UNWCC, $77^{\text {th }}$ Mtg 77, see earlier discussions at M35, M36, M41.

${ }^{63}$ Trial of Takashi Sakai, United Nations War Crimes Commission, XIV Law Reports of Trials of War Criminals 1, Case No. 83, Chinese War Crimes Military Tribunal of the Ministry of National Defence, Nanking, 29 August 1946.

${ }^{64}$ History of the UNWCC (n 1) 10.

${ }^{65}$ The Kampala Conference defined the crime of aggression as "the planning, preparation, initiation or execution, by a person in a position effectively to exercise control over or to direct the political or military action of a State, of an act of aggression which, by its character, gravity and scale, constitutes a manifest violation of the Charter of the United Nations".
} 
peace. Both the Yugoslav and Greek courts were empowered to pursue these types of cases. ${ }^{66}$ The London Charter for the IMT influenced the subsequent provisions of the US Military Tribunals and regulations in the Pacific and China although it is not clear whether these provisions were enacted. ${ }^{67}$ These Balkan and Asian examples of municipal practice indicate a wider application of crimes against peace than is usually assumed.

\subsection{The Defence of Superior Orders}

The question of the validity of the defense of superior orders was also debated throughout the duration of the Commission. The Commission was unanimous that "the mere fact of having acted in obedience to the orders of a superior does not of itself relieve a person who has committed a war crime from responsibility", though it did not seek to impose this view on its members. ${ }^{68}$ Many individuals accused in the national trials pled the defense of superior orders in their trials. These pleas were often anticipated by the members of the Commission and highlighted in numerous debates seeking to address "the extent to which persons pledged by law to obey orders of their superiors, in particular those issued by heads of State and Governments, were to be held personally responsible for acts committed by them in in subordinate positions". ${ }^{69}$ The issue was viewed as significant enough that Committee III appointed a small sub-committee to address the issue and reach solutions.

Historical contention around the issue complicated the duty of the Commission to clarify the principle. There is at least one circumstance at the Leipzig Trials of the acquittal of an officer of sinking a hospital ship on the grounds that he had acted in obedience to orders from a superior. German law at that time held that the defence of superior orders was valid. ${ }^{70}$ After great amounts of debate, the official statement of the Commission was, "civil and military authorities cannot be relieved from responsibility by the mere fact that a higher authority might have been convicted of the same offence. It will be for the court to decide whether a plea of superior orders is sufficient

\footnotetext{
${ }^{66}$ Information Concerning Human Rights Arising from Trials of War Criminals (n 5) 288, 295-297.

${ }^{67}$ Ibid., 158.

${ }^{68}$ Report to the Governments on the Plea of Superior Orders, UNWCC, C86, M54,2.

${ }^{69}$ History of the UNWCC (n 1) 263.

${ }^{70}$ See the case of Lieutenant-Commander Karl Neumann, commander of the submarine U. 67 and the case of the sinking of the Hospital Ship 'Dover Castle' on 26 May 1917.
} 
to acquit the person charged from responsibility". ${ }^{71}$ Along these lines, one of the key issues that the Commission addressed in its discussions was the legal conundrum presented by traditional standards of immunity for state officials and the ubiquitous practice of state officials issuing orders to subordinates to engage in illegal action. This discussion is echoed in the Commission's report to the UN in $1948 .^{72}$ This report also discusses criminal liability for keeping watch while a crime is committed, passing on orders, participating in lynching, instigating crime and common design. ${ }^{73}$ Ultimately, Wright expressed in his introduction to History of the UNWCC, that "I think it can now be taken as settled that [the] plea is not a sufficient defence but that it may have effect by way of extenuation". 74

\subsection{Environmental Degradation}

As the Commission was closing its operations in 1948, the Polish government brought forth two cases involving degradation of forestland for review. While the case never reached trial due to the closure of the UNWCC, the notes to the charge file shed light on this issue before the Commission. The representatives specifically asked for the Commission to determine whether or not the suspected criminals could be charged with war crimes for their policies and actions. In a charge file received first by the Commission on 11 December 1947 and again in revised form on 20 January 1948, the Polish national office accused eleven people of pillage of public forests as a war crime. The people accused included the chief of the forestry department of the region in question, as well as the head forestry administrators in Kracow, Warsaw and Radom. The date of the alleged crime included acts committed during the duration of office as heads of respective departments of the Forestry Administration in Poland under the German Occupation from 1939 1944. The individuals are specifically accused of taking part in having "wrought a tremendous devastation to Polish forests" 75 The charge file claims that this had a significant economic impact on the country due to sizeable losses in revenue due to the stolen timber.

A second case filed on 18 December 1947 accused another Nazi in the occupying force of "wanton destruction of public property" specifically for "ill-treat[ing] the Poles without any

${ }^{71}$ History of the UNWCC (n 1) 138.

${ }^{72}$ UN E/CN.14-AM9 (1948) 217-236.

${ }^{73}$ Ibid., 212-216.

${ }^{74}$ History of the UNWCC (n 1) 11.

${ }^{75}$ Please insert reference. 
reason whatsoever and allow[ing] for devastation of forests" in his capacity as deputy director of the district of Garwolin, Poland during the period of $1943-1944 .^{76}$ It was alleged that all of the individuals involved in the two cases used the positions of power that they occupied to promote the irresponsible cutting of excessive amounts of Poland's forestry. This occurred to the detriment of the environment as well as the Polish economy, the accusations contend. The Commission was able to get as far as determining that prima facie evidence existed suggesting that a war crime was committed. Nine of the individuals were accused in the first case and listed as war criminals by the Commission. ${ }^{77}$ Further research needs to be conducted into whether Poland conducted the trial of the nine accused.

In the past several decades "blood diamonds" and "agent orange" have become common phrases associated with war and the environment as well as economic gain. Currently, control of access to natural resources continues to provoke conflict between nations and armed groups around the world. Resource plunder is blamed for causing devastation related to environmental, economic and health-related well-being of millions of people and natural spaces. Millions of lives have been lost as well as millions of dollars and millions of acres of natural land. Despite the devastating realities of environmental crimes committed during the wars in the former Yugoslavia, Rwanda, Sierra Leone and Cambodia, none of the international ad-hoc tribunals have issued charges related to environmental degradation.

The Rome Statute of the ICC contains a possible basis to prosecute elements of environmental degradation as part of war crimes law. Article 8(2) addresses the protection of private and public property against pillage during times of war. Article 8(2)(a)(iv) prohibits "[e]xtensive destruction and appropriation of property, not justified by military necessity and carried out unlawfully and wantonly". Article 8(2)(b)(iii) outlaws indiscriminate attacks, i.e. "intentionally launching an attack in the knowledge that such attack will cause incidental loss of life or injury to civilians or damage to civilian objects or widespread, long-term and severe damage to the natural environment which would clearly be excessive in relation to the concrete and direct overall military advantage anticipated". These actions are considered to be war crimes over which the Court has jurisdiction. While these two provisions demonstrate commitment by the ICC to prosecute pillage of public property occurring in both international and national

\footnotetext{
${ }^{76}$ Please insert reference.

${ }^{77}$ History of the UNWCC (n 1) 496.
} 
conflicts, both reference possible exceptions. In the case of Article 8(2)(a)(iv) for justification "by military necessity" and in the case of Article 8(2)(b)(iii) for acts "excessive in relation to...military advantage anticipated". Currently no criminal cases concerning resource plunder or environmental degradation have been presented to the ICC.

There is legal precedent for the prosecution of pillage of private and public property as a war crime including in cases of the UNWCC and its inclusion in the Rome Statute. ${ }^{78}$ However, this case that was brought to the UNWCC's attention specifically for environmental damage is cause for consideration of this principle on separate grounds that would recognize the environmental implications of such crimes in addition to the economic factors inherent in charges of pillage of private and public property.

\section{CRITICISMS}

It is important to note that several criticisms plagued the UNWCC throughout its operation and following its closure. On the one hand, sections of the US and UK governments dedicated little time for the idea of war crimes trials including for an international process, and this was reflected in their commitment. On the other, the Commission was criticized precisely because it was not a fully functional system of law and order, apprehending suspects and bringing them to trial. Another general criticism of the Commission was that it had to conduct most of its work in secret due to security issues concerning the timing and scale of its work. This factor is especially evident when the Commission is compared to the IMTs, as the IMTs acted for the world to try the more notorious criminals and were backed by hefty budgets and public attention.

Perhaps the most significant criticism was that the Commission's limited power did not include the executive capacity to prosecute war criminals directly, which led to a significant reliance on the different governments to execute trials and achieve justice. This specific factor has generated criticism that the practices of the nations were not entirely uniform or consistent as each had very different economic and political capacities following the war. Historian Dr. Effie

\footnotetext{
${ }^{78}$ See Rome Statute of the International Criminal Court (2002) 2187 UNTS 90, Articles 8(2) (b) (xvi), 8(2) (e) (v),. For a study of legal precedents, see J. Stewart, 'Corporate War Crimes: Prosecuting the Pillage of Natural Resources', (2011), Annex 1, <http://www.opensocietyfoundations.org/sites/default/files/pillage-manual-2nd-edition-2011.pdf>; L. van den Herik \& D. Dam-De Jong, 'Revitalizing the Antique War Crime of Pillage: The Potential and Pitfalls of Using International Criminal Law to Address Illegal Resource Exploitation' (2011) 22 Criminal Law Forum 237273.
} 
Pedaliu argues that the process of putting war criminals on trial was slowed down considerably because the UNWCC was merely an advisory body with no executive powers. ${ }^{79}$

Related to this are general criticisms about the legal processes employed by the different nations operating under the umbrella of the UNWCC. These include lack of appeal options for people convicted in the trials and the investigation and judicial processes that are viewed by some critics as hasty. The UNWCC and the IMTs are all criticised as exemplifying victors' justice. Certainly if there had been no victory there would have been no trials and as far as it went, justice. However, it is clear that all the states concerned from the St James's Declaration onwards focused political energy on exactly this issue. They rejected mob rule, warned the enemy they would be placed on trial, chose to subject their national prosecutions to international approval, constructed standards of evidence, agreed recommendations on what was and was not an international crime in extensive detail, rejected some proposed prosecutions and when trials were conducted acquitted a significant number of defendants. In all of this they sought and achieved their strategic goal of demonstrating the civilized nature of their states in contrast to those of their attackers.

We recognize that general context marked by a deep sense of urgency and the political dynamics of the World War II /early Cold War period stinted the UNWCC's ability to function and its overall success. The most obvious of these is the Soviet Union's refusal to participate in the Commission and their establishment of an independent entity to address war crimes. Less obvious, but argued publicly by Herbert Pell at the time and most recently by Cox and Simpson in this symposium, are the negative influences of dominant sections of the US and British governments that grew in intensity throughout the life of the Commission. Kochavi calls "Britain's differences of opinion with the Soviets" ${ }^{80}$ a downside of the Commission.

Finally, the hasty and premature close of the UNWCC generated confusion and criticism at the time and also into the future. The closure led to the incomplete recording of statistics about the national and military trials and the number of people involved in investigations. In its final document sent to the UN in 1948 and in History of the UNWCC, the Commission's members acknowledged many of the limitations and urged further study of the work that had been

\footnotetext{
${ }^{79}$ E. G. H. Pedaliu 'Britain and the "Hand-over" of Italian War Criminals to Yugoslavia, 1945-1948' (2004), 39 Journal of Contemporary History 509.

${ }^{80}$ A. J. Kochavi, (n 1) 336.
} 
achieved. The fact that this never happened is itself powerful evidence of the influence of those who were opposed to its work.

\section{LEGACY}

The main legacy of the Commission can be summed up with the cliché that Nuremberg was just the tip of the iceberg of international criminal prosecutions at the end of World War II. Based on the work of the Commission, global governance in the present century fosters debate regarding the political will to pursue suspected war criminals, not against the benchmark of Tokyo and Nuremburg, but against the standard that dozens of agencies, courts and tribunals pursued tens of thousands of cases of international crimes against individuals at all levels of authority. While existing literature related to World War II and the prosecution of Axis war criminals generally gives the UNWCC only scarce attention and recognition, the Commission's actual influence in this period is significant. It is true that not all war criminals of both major and mid-level stature faced prosecution following the end of the war. However, it is certain that while some escaped, many were subjected to trials and punishment. This is particularly important when viewed alongside the largely unsuccessful efforts to initiate international criminal justice efforts after World War I. Indeed, fair trials and punishment are regarded as central to international criminal law seventy years later.

Decisions and opinions of the UNWCC carried the weight of the participating states. This stands in direct contrast to the Four-Power London Charter for the IMT that was adhered to without substantive input by other states. It also stands in contrast to the Control Order 10 processes that carried the weight of one or several states. It is important to note that the military tribunal cases such as those known as the Belsen and Dachau trials were given prima facie approval by all of the members of the Commission adding the to strength of the legal process. The advocacy of improved prosecution today may be assisted by reminding governments where their historic policy and practice was in advance of that of today, especially where the experience of World War II has assumed a foundational and defining part of national culture.

One key legacy of the UNWCC is its direct influence on the Nuremberg Charter and subsequently the proceedings at Nuremberg and Tokyo. The support that the Commission provided to Nuremberg is rarely referenced in modern literature concerning the topic. Indeed, 
Justice Robert Jackson visited the Commission in London during the summer of 1945 and cited specific issues debated by the Commission that he planned to adopt at Nuremberg. ${ }^{81}$ The Commission demonstrates that issues of race and gender are important in twenty first century considerations of judicial processes for international crimes. While more research is needed, it is clear that both dimensions were present in the 1940s in ways that are not usually recognized. One important example of this is China and India's active participation in the UNWCC operations. Both of the countries consistent involvement in the general Commission meetings as well as the Committee meetings provides a substantial non-Western contribution. China took a leading role in the investigation and trial work conducted in the Far East through its leadership of the work of the Far East Sub-Commission. ${ }^{82}$ Despite not being an independent state, India had representation on the UNWCC from the very beginning of its operations and remained active even after it gained independence in 1947. Indian judges also participated in some of the tribunals in the Far East. $^{83}$

As is discussed, gender based crimes were pursued at this time, but it is also important to note that women were also active members of the Commission and served in some occasions as national representatives. The minutes of the Commission show the governments of Denmark, France and the Netherlands were at various times represented by women. ${ }^{84}$

\section{THE FUTURE RESEARCH AGENDA}

The contemporary research into the work of the UNWCC and its associated courts and tribunals has several components. The most important is to empower advocacy for the international and national enforcement of punishment for international crimes against human rights as an objective in its own right and as a means of fulfilling the intent of the Commissioners themselves. This work requires an application of the work of the practices of the 1940s, where they are appropriate to present day conditions based on a growing understanding of those past practices. This understanding requires a full compilation and synthesis of archival material especially including

\footnotetext{
${ }^{81}$ For more information about the UNWCC's contribution to the Nuremberg trials, see History of the UNWCC (n 1) chapter XIV.

${ }^{82}$ Ibid., 130.

${ }^{83}$ Sir Samuel Runganadhan was India's first representative to the UNWCC, followed by Mr. Dutt.

${ }^{84}$ See Committee I Mtg. (19 July 1946). France's Mlle Capiomont and Norway's Miss Raag are listed as 'Members of the Commission and representatives of the National Offices'.
} 
the pre-trial files prepared for the Commission by states setting out charges and the records of subsequent trials.

There is also great relevance in evaluating the operational structure of the UNWCC in the context of the tribunals in operation today, specifically the International Criminal Tribunal for the former Yugoslavia (ICTY), the International Criminal Tribunal for Rwanda (ICTR), the Special Court for Sierra Leone (SCSL) and the Extraordinary Chambers in the Courts of Cambodia (ECCC). Specific points for further research and comparison on the organizational aspects include the subject of a global system of complementary justice that effectively supports attempts being made by municipal authorities, overall costs of operation, the duration of trials and the interplay between international and national systems of justice. The requirements of fair trials was given much attention by the Commission and any analyses of those it supported should include both contemporary practice outside the arena of war crimes and the not unproblematic practices of today. Wright wrote that "[i]t was widely felt that justice should not be delayed" 85 specifically citing on other occasions that delays would mean complications and "escape of [the] guilty" ${ }^{86}$ Most UNWCC-supported trials lasted between four and five days to three weeks.

Another aspect not addressed in the articles in this symposium and worth further study is the attention given by the UNWCC to mid-level criminals. This upholds the principles of international criminal law of deterrence and achievement of justice; senior-level authoritarians do not plan and wage aggressive war by themselves. As a result of this priority, the UNWCC performed the largest role in addressing Nazi war crimes. Currently, it is widely acknowledged that the UN tribunals are moving away from mid-level criminals and are focusing primarily on senior-level officials.

\section{CONCLUSION}

While worthy of some criticism and skepticism, the UNWCC does not deserve to be neglected by historical narratives that are often influenced to a great degree by political manoeuvring. Its accomplishments are many, in particular when viewed in context of the scale and scope of the destruction of World War II and the great needs required to bring justice to the international

\footnotetext{
${ }^{85}$ History of the United Nations War Crimes Commission and the Development of Laws of War,(n 1 above) 4.

${ }^{86}$ Ibid., 109.
} 
community. Indeed, states party to the Commission made a number of specific and enduring advances in international criminal law. Some of these we have discussed elsewhere or are the subject other articles in this symposium or both; some which we introduce here and some which we mention as part of the future research agenda. Our and our colleagues research address the crimes of aggression ${ }^{87}$, crimes against humanity ${ }^{88}$, collective responsibility ${ }^{89}$, sexual violence ${ }^{90}$, torture $^{91}$, the development of an international criminal court ${ }^{92}$, systems of complementary justice $^{93}$ and facts and evidence ${ }^{94}$.

We hope that this overview of the work and structure of the Commission and the accompanying articles in thissymposium serve to draw attention to the UNWCC, its relevance to current debates and the need for further study of the trials that it supported as well as the legal discussions it fostered. With this deepened insight, we believe that greater precedent will be uncovered for the upholding of human rights standards in the context of conflict by the international community.

\footnotetext{
${ }^{87}$ See 'Changing the Paradigm of International Criminal Law: Considering the Work of the United Nations War Crimes Commission of 1943 - 1948', 15 The International Community Law Review 203-223.

${ }^{88}$ See contributions by H. Rhea, G. Cox and C. Simpson in this volume.

${ }^{89}$ See contribution by K. Hale and D. Cline in this volume.

90 'Changing the Paradigm of International Criminal Law' (n 85 above) and the contribution by S. SaCouto, C. Lasco and D. Plesch in this volume.

${ }^{91}$ See contributions by L. Oette and W. Form in this volume.

${ }^{92}$ See the contributions by W. Schabas in this volume.

${ }^{93}$ See the contribution by M. Ellis in this volume.

${ }^{94}$ See the contribution by C. Stahn in this volume.
} 